\title{
Simultaneous determination of six auxin plant growth promoters in agricultural products by liquid chromatography tandem mass spectrometry (LC-MS/MS)
}

\author{
Vu Ngoc Tu ${ }^{1,2 *}$, Dang Thi Hien ${ }^{1,2}$, Nguyen Thi Anh Huong ${ }^{2}$, Pham Thi Ngoc Mai \\ Hoang Quoc Anh ${ }^{2}$, Bui Cao Tien ${ }^{1}$, Bui Quang Dong1, Le Thi Hong Hao ${ }^{1,2}$, Tran Cao Son ${ }^{1}$ \\ ${ }^{1}$ National Institute for Food Control, Hanoi \\ ${ }^{2}$ University of Science, Vietnam National University, Hanoi
}

(Received: 26/3/2020; Accepted: 15/6/2020)

\section{Abstract}

A highly sensitive and specific method for simultaneous determination of six synthetic auxins (4-chlorophenoxyacetic acid (4-CPA), 2-methyl-4-chlorophenoxyacetic acid (MCPA), 1-naphthalene acetic acid (NAA), 2-napthoxyacetic acid (NOA), indole-3-propionic acid (IPA), indole-3-butyric acid (IBA)) were developed using a QuEChERS-based sample extraction followed by an LC-MS/MS analysis. The method was validated and proved to meet the AOAC International requirements for specificity, sensitivity, and accuracy in the range of 3.0 and 200 $\mu \mathrm{g} / \mathrm{kg}$. LOD and LOQ of all analytes were at $1.0 \mu \mathrm{g} / \mathrm{kg}$ and $3.0 \mu \mathrm{g} / \mathrm{kg}$, respectively. The recoveries of six synthetic auxins were from $78.9 \%$ to $96.4 \%$ and the repeatability relative standard deviations were below $12.6 \%$. The method was applied to simultaneously determine the content of 4-CPA, MCPA, NAA, NOA, IPA, IBA in vegetables, tubers, and fruits samples collected from different markets in Hanoi (Mai Dich, Dan Phuong, Giap Bat, Bach Mai, and Nga Tu So). MCPA was detected in $22 / 30$ vegetable samples $(3.0 \div 7.1 \mu \mathrm{g} / \mathrm{kg}), 9 / 30$ tuber samples $(3.2 \div 3.7 \mu \mathrm{g} / \mathrm{kg}) ; 4-\mathrm{CPA}$ was detected in bean sprouts in the range from 23 to $75 \mu \mathrm{g} / \mathrm{kg}$ which exceeded the Maximum Residue Levels (MRL) of $10 \mu \mathrm{g} / \mathrm{kg}$ set by European Commission.

Keywords: 4-chlorophenoxyacetic acid (4-CPA), 2-methyl-4-chlorophenoxyacetic acid (MCPA), 1-naphthalene acetic acid (NAA), 2-napthoxyacetic acid (NOA), indole-3-propionic acid (IPA), indole-3-butyric acid (IBA), LC-MS/MS, QuEChERS, auxin, vegetables, tuber, fruit

\section{INTRODUCTION}

Many plants are indispensable parts of the daily meals and play an important role in human nutrition and health. The presence of substances called "Auxin" suggested a good choice of plant-growth regulator (PGR) products in agriculture because it replaced the massive use of pesticides, fertilizer by a greener product. Auxins are natural important regulators produced by plants and they are usually in low concentrations. Auxin group includes auxin natural metabolites (indole-3-propionic acid (IPA), indole-3-butyric acid (IBA)) which are endogenous compounds of plants that have similar effects as $\beta$-indol-acetic acid (IAA) and synthetic auxin analogs (4-chlorophenoxyacetic acid (4-CPA), 2-methyl-4-chlorophenoxyacetic acid (MCPA), 1-naphthalene acetic acid (NAA), 2-napthoxyacetic acid (NOA)). They regulate processes such as growth differentiation, metabolism, morphogenesis in plants. Nowadays, in Vietnam, several auxin analogs are applied widely in agriculture and horticulture. However, the abuse of these substances can lead to a high level of PGR residues in agricultural products, which are harmful to consumer's health. Many intoxication cases were recorded due to consuming bean sprouts or

\footnotetext{
*Corresponding author:Tel 0984459988 Email:vungoctu1986@gmail.com
} 
vegetables containing excessively high content of PGRs [1-2].

Sample preparation is considered as the main step in analyzing auxins. Recently, QuEChERS is the method widely used for determining auxin contents in fruit, vegetables because of its low cost and time-saving. For separation and detection, GC-MS is the classical method of auxin quantification which provides high sensitivity, however, its disadvantage is an obligatory derivation including silylation and methylation [3-4]. The immunoassays such as RIA and ELISA are time-consuming and complicated sample preparation methods used for quantifying auxin. Even though, ELISA method is less sensitive than GC/MS and LC/MS. When comparing to the aforementioned methods, the LC-MS/MS method provides many outstanding advantages such as simple sample preparation procedure and, most importantly, the capacity of simultaneous analysis of a large number of substances with high specificity, sensitivity, and accuracy [5-6]. At present, there has been no standard method for simultaneous determination of all 06 auxin analogs in vegetables, fruits, and tubers in Vietnam.

The objective of this study was to develop and validate an LC-MS/MS method for simultaneous determination of six auxin analogs, providing a technical solution for the better control of food quality in Vietnam, and to apply the developed method for investigating the actual residual levels of these substances in commercial vegetables, tubers, and fruits.

\section{MATERIALS AND METHODS}

\subsection{Standards}

Standard substances of 1-naphthalene acetic acid, 2-naphthoxyacetic acid, 4-chlorophenoxyacetic acid, 2-methyl-4-chlorophenoxyacetic acid, 3-(3-indolyl) propionic acid, indole-3butyric acid were obtained from LGC (Germany).

The individual stock standard solutions of $1.000 \mu \mathrm{g} / \mathrm{mL}$ were prepared in acetonitrile and stored at $-18^{\circ} \mathrm{C}$. The mixed-standard solution of six auxin analogs of $10 \mu \mathrm{g} / \mathrm{mL}$ was also prepared in acetonitrile and was used to make the working standard solution from 3.0 to $200 \mathrm{ng} / \mathrm{mL}$ in the blank extract.

\subsection{Reagents}

Solvents and chemicals including methanol, formic acid, anhydrous magnesium sulfate, sodium chloride, and acetic acid all of pure analysis standard and acetonitrile of HPLC standard were purchased from Merck (Germany). Water was produced by a water purification system (Merck Millipore, Germany). Primary secondary amines (PSA) and C18 sorbents were purchased from Agilent (USA).

Blank samples used for method development and validation were bean sprout, spinach, and potato which were collected from organic vegetable and fruit stores in Hanoi.

\subsection{Instrumentation}

Liquid chromatography system Exion LC 20AD (Sciex, USA) coupled with detector AB SCIEX Triple Quad 6500+ (Sciex, USA) was used in this study. Other equipment used includes shaking incubator (Amerex, USA), $\mathrm{pH}$ meter (Metter Toledo, Switzerland), analytical balance (Metter Toledo, Switzerland), centrifuge (Hettich, Germany), vortex mixer (IKA, China), ultrasonic bath (Elma, Germany).

\subsection{Method development}

Mass spectrometry conditions were optimized to identify the two transitions with precursor 
and product ions of each analyte. Then, liquid chromatographic conditions (chromatographic column, mobile phase composition, and gradient program) were selected.

Based on consulting other scientific papers [7-8], the QuEChERS technique was selected. The proposed procedure was as follows: about $10 \pm 0.01 \mathrm{~g}$ of the homogenized sample was accurately weighed into a $50 \mathrm{~mL}$ centrifuge tube $10 \mathrm{~mL}$ of acetonitrile solution was then added into the tube, and the tube was shaken vigorously within 1 minute. After that, the salt mixture containing $4 \mathrm{~g}$ of anhydrous $\mathrm{MgSO}_{4}, 1 \mathrm{~g}$ of $\mathrm{CH}_{3} \mathrm{COONa}$ was added into the tube, then the tube was capped and shaken vigorously within 2 minutes and centrifuged within 5 minutes at 6.000 $\mathrm{rpm} .1 \mathrm{~mL}$ of the supernatant was transferred accurately into a $2 \mathrm{~mL}$ centrifuge tube containing

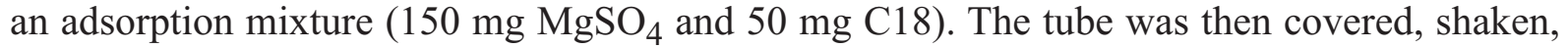
and centrifuged within 3 minutes at $13.000 \mathrm{rpm}$. A suitable portion of supernatant was transferred to a vial prior to being analyzed by LC-MS/MS.

Three sample preparation steps including extracting solvent, dispersion sorbent, and mixing technique were investigated and optimized. The blank samples were spiked with a mixed standard solution of $100 \mu \mathrm{g} / \mathrm{kg}$ of six targeted analytes and the sample preparation was optimized following the initially proposed procedure described above.

\subsection{Method validation}

The method was validated in terms of specificity, limit of detection, limit of quantification, linearity, precision (repeatability), trueness (recovery) in three matrices including bean sprout, spinach, and potato. Validation data were assessed following the requirements of the EU (EC/657/2002) and AOAC International.

\subsection{Method application in agricultural products}

Ninety samples of vegetables, fruits, and tubers (30 samples of each kind) were randomly purchased in supermarkets and commercial centers in Hanoi. The validated method was applied to detect and quantify the content of the six auxin analogs which was compared to the default maximum residue limit (MRL) of $10 \mu \mathrm{g} / \mathrm{kg}$ set by EU.

\section{RESULTS AND DISCUSSION}

\subsection{LC-MS/MS condition optimization}

\subsubsection{Selection of mass spectrometry conditions}

Precursor and product ions of six auxin analogs were optimized by directly infused of 1.0 $\mu \mathrm{g} / \mathrm{mL}$ standard solutions into the mass spectrometry system. The product ions which gave the highest intensity and stability were used for the quantitation and the other was for confirmation purpose. The MS/MS transitions with optimized collision energies were shown in Table 1.

Table 1. MS/MS conditions of six auxins

\begin{tabular}{lccc}
\hline Analyte & $\begin{array}{c}\text { Precursor ion } \\
(\mathbf{m} / \mathbf{z})\end{array}$ & $\begin{array}{c}\text { Product ions } \\
(\mathbf{m} / \mathbf{z})\end{array}$ & $\begin{array}{c}\text { Collision } \\
\text { energy }(\mathbf{e V})\end{array}$ \\
\hline 1-naphthalene acetic acid & 185.0 & 127.0 & $-18^{\mathrm{a}}$ \\
& & 140.9 & -12 \\
2-naphthoxyacetic acid & 201.1 & 142.8 & $-20^{\mathrm{a}}$ \\
& & 115.0 & -52
\end{tabular}




\begin{tabular}{lccc}
\hline Analyte & $\begin{array}{c}\text { Precursor ion } \\
(\mathbf{m} / \mathbf{z})\end{array}$ & $\begin{array}{c}\text { Product ions } \\
(\mathbf{m} / \mathbf{z})\end{array}$ & $\begin{array}{c}\text { Collision } \\
\text { energy }(\mathbf{e V})\end{array}$ \\
\hline 4-chlorophenoxyacetic acid & 185.0 & 126.9 & $-20^{\mathrm{a}}$ \\
& & 129.0 & -20 \\
2-methyl-4-chlorophenoxyacetic acid & 199.0 & 141.0 & $-21^{\mathrm{a}}$ \\
& & 143.0 & -21 \\
3-(3-indolyl) propionic acid & 190.1 & 130.2 & $35^{\mathrm{a}}$ \\
& & 77.1 & 65 \\
Indole-3-butyric acid & 204.0 & 186.0 & $19^{\mathrm{a}}$ \\
& & 130.2 & 35 \\
\hline
\end{tabular}

${ }^{a}$ Quantification ion

\subsubsection{Investigation of liquid chromatography conditions}

The studied analytes are substances with low polarity to medium polarity, able to interact well with the poorly polarized phase of column C18. In this study, the UPLC BEH C18 column $(2.1 \times 50 \mathrm{~mm} ; 1.7 \mu \mathrm{m}$ particle size) was used to conduct further steps. The gradient composition of water, methanol, and acetonitrile with the addition of ionic additives was investigated to select the proper mobile phase condition. From the survey, the appropriate gradient program to elute the analytes was selected and shown in Table 2.

Table 2. Mobile phase gradient condition

\begin{tabular}{lccc}
\hline $\begin{array}{l}\text { Time } \\
\text { (min) }\end{array}$ & $\begin{array}{c}\text { \% } \boldsymbol{A} \\
(\text { HCOOH 0,1\% /H2O) }\end{array}$ & $\begin{array}{c}\text { \% B } \\
(\boldsymbol{A C N})\end{array}$ & $\begin{array}{c}\text { Flow rate } \\
(\mathbf{m L} / \text { min })\end{array}$ \\
\hline 0.0 & 90 & 10 & 0.3 \\
1.5 & 10 & 90 & 0.3 \\
4.5 & 10 & 90 & 0.3 \\
4.6 & 90 & 10 & 0.3 \\
6.0 & 90 & 10 & 0.3 \\
\hline
\end{tabular}

\subsection{Investigation of the sample preparation}

\subsubsection{Selection of extraction solvent}

The type of extraction solvent is very important in determining the extraction efficiency of the process. The analysis was carried out with 5 solvents: ACN, $0.1 \%$ acetic acid in ACN, $1 \%$ acetic acid in $\mathrm{ACN}, \mathrm{ACN}, 0.1 \%$ formic acid in $\mathrm{ACN}$, and $1 \%$ formic acid in ACN. The result was given in Figure 1.

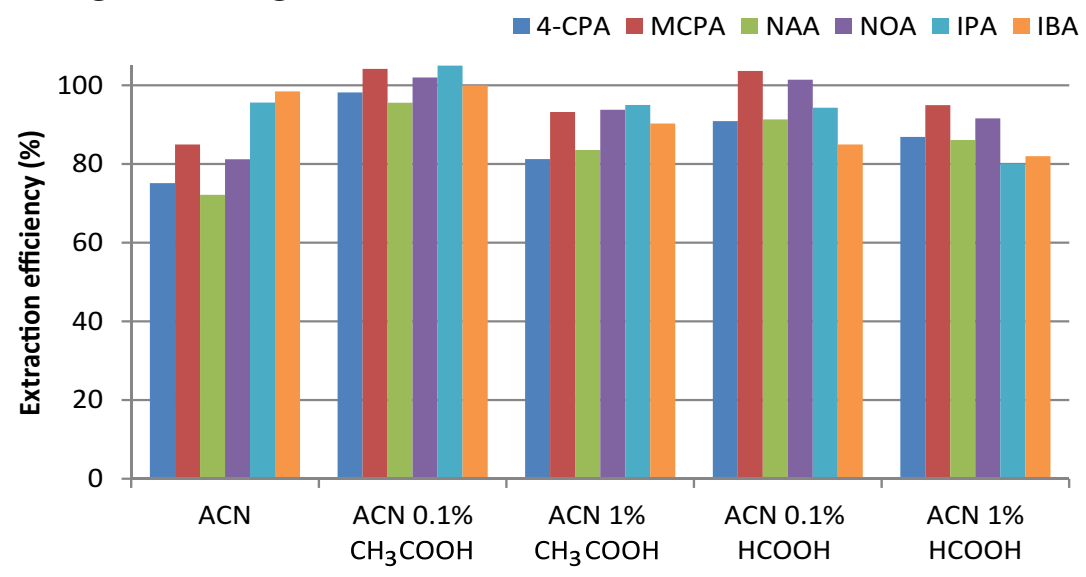

Figure 1. The extraction efficiency of different extraction solvent mixtures 
Extraction efficiency for ACN was lowest for 4-CPA, MCPA, NAA, and NOA compared to other solvents, which is explained that the acidic solvent helps protect acidic analytes from degeneration. The results also pointed out that the acetonitrile containing $0.1 \%$ acetic acid solvent provides the best extraction efficiency. Therefore, $0.1 \% \mathrm{CH}_{3} \mathrm{COOH}$ in $\mathrm{ACN}$ solvent was selected for further investigation.

\subsubsection{Investigation of adsorption mixture}

We have investigated three adsorption mixtures which include: $50 \mathrm{mg}$ PSA $+150 \mathrm{mg}$ $\mathrm{MgSO}_{4}$ (mixture 1); $25 \mathrm{mg} \mathrm{C} 18+25 \mathrm{mg} \mathrm{PSA}+150 \mathrm{mg} \mathrm{MgSO}$ (mixture 2), $50 \mathrm{mg} \mathrm{C} 18+150$ $\mathrm{mg} \mathrm{MgSO}_{4}$ (mixture 3). The extraction efficiencies corresponding with using 3 kinds of adsorption mixtures were illustrated in Figure 2.

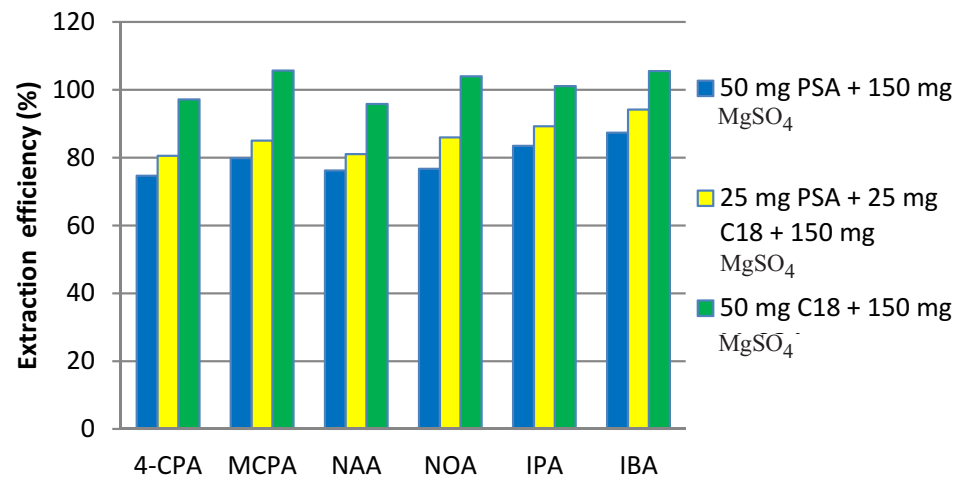

Figure 2. The extraction efficiency of different adsorption mixtures

As can be seen from Figure 2, the highest extraction efficiency was obtained with mixture

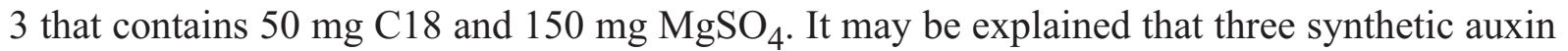
analogs all have the carboxylic acid functional group - $\mathrm{COOH}$ in their molecule. The $-\mathrm{COOH}$ group can react with PSA and lead to the loss of the analytes during the purification step. The addition of $\mathrm{C} 18$ sorbent helps remove some fatty content in some types of agricultural products. Therefore, C18 was better for cleaning in the d-SPE step and mixture 3 was selected for the following investigation steps.

\subsubsection{Investigation of mixing technique}

After adding extract solvent, the solid-liquid extraction step was conducted with 2 different techniques as shaking the tube manually at different shaking times from 60 to 180 seconds, and shaking the tube manually in 30 seconds followed by ultrasonic vibration for 30 seconds. Extraction efficiencies were presented in Figure 3 for comparison.

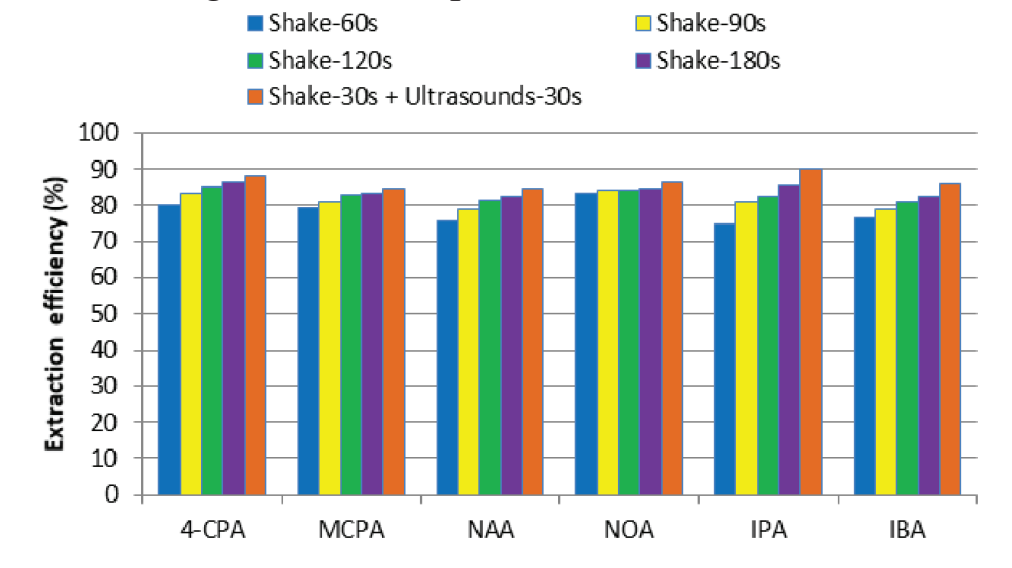

Figure 3. The extraction efficiency of different mixing techniques 
The largest extracted amounts of analytes obtained when the sample was manually shaken within 30 seconds then followed by ultrasound vibration in 30 seconds. Therefore, the combination of manual shaking and ultrasound vibration in 30 seconds was the optimal condition for this step.

\subsection{Method validation}

\subsubsection{Specificity}

The blank samples, standard and spiked samples with a concentration of each auxin at 20 $\mu \mathrm{g} / \mathrm{kg}$ in bean sprout, spinach, and potato matrix were analyzed using the optimized method. An example of chromatograms of 4-CPA in bean sprout is presented in Figure 4. Similar results were obtained for other compounds in other matrices. The blank matrices did not give the significant signal at the retention time of the analytes; while the spike samples gave a peak at the similar retention time of the standard. These results prove the specificity of the method.

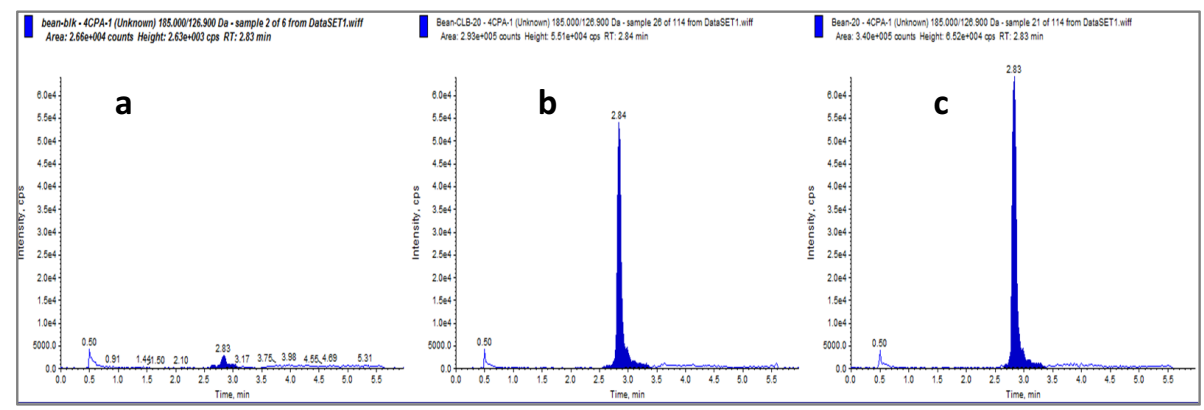

Figure 4. Chromatograms of (a) blank sample, (b) standard solution of $20 \mathrm{ng} / \mathrm{mL}$ and (c) spiked sample at $20 \mathrm{ng} / \mathrm{mL}$

For mass spectrometry, the ratio of ions is one of the criteria to confirm the presence of an analyte. The ion ratio is the percentage of the lower signal product ion divided to the higher one of the same precursor ion. The identification points and the ion ratios of standard solution and spiked samples, presented in Table 3, meet the requirements of EU regulation. The deviation of spiked sample when comparing with the results of standard solution varied from -22.86 to $7.69 \%$, which confirms the highly specified method.

Table 3. Identification point and ion ratio of 06 auxin analogs

\begin{tabular}{cccccc}
\hline Analyte & IP & $\begin{array}{c}\text { Standard } \\
\text { solution }\end{array}$ & $\begin{array}{c}\text { Spiked-blank } \\
\text { sample }\end{array}$ & $\begin{array}{c}\text { Deviation } \\
\text { (\%) }\end{array}$ & $\begin{array}{c}\text { Maximum } \\
\text { deviation (\%) }\end{array}$ \\
\hline 4-CPA & 4 & 28 & 29 & 3.57 & $\pm 30 \%$ \\
MCPA & 4 & 81 & 84 & 3.70 & $\pm 30 \%$ \\
NAA & 4 & 25 & 24 & -4.00 & $\pm 30 \%$ \\
NOA & 4 & 13 & 14 & 7.69 & $\pm 30 \%$ \\
IBA & 4 & 49 & 46 & -6.12 & $\pm 30 \%$ \\
IPA & 4 & 35 & 27 & -22.86 & $\pm 30 \%$ \\
\hline
\end{tabular}

\subsubsection{Limit of detection (LOD) and limit of quantification (LOQ)}

LOD and LOQ of the method were determined by using signal to noise $(\mathrm{S} / \mathrm{N})$ ratio method. The spiked samples at three concentrations of $1.0,3.0,10 \mu \mathrm{g} / \mathrm{kg}$ for six auxins were analyzed and the $\mathrm{S} / \mathrm{N}$ ratio for each analyte was calculated. At the spiked level of $1.0 \mu \mathrm{g} / \mathrm{kg}$ and $3.0 \mu \mathrm{g} / \mathrm{kg}$, the $\mathrm{S} / \mathrm{N}$ ratio was higher than 3 and 10, respectively. Therefore, it could be concluded that the 
LOD and the LOQ of the method are $1.0 \mu \mathrm{g} / \mathrm{kg}$ and $3.0 \mu \mathrm{g} / \mathrm{kg}$, respectively. With the LOQ of $3.0 \mu \mathrm{g} / \mathrm{kg}$, the method has sufficient efficiency to access the growth hormone promoters in food samples following the EU's MRL of $10 \mu \mathrm{g} / \mathrm{kg}$.

\subsubsection{Calibration curve}

The matrix-matched standard solutions were made by the addition of mixed standard solution into blank extract at the concentrations of 3.0,10,20,50,100, and $200 \mu \mathrm{g} / \mathrm{kg}$, then was analyzed by LC-MS/MS method to determine the linearity of the method. The result showed good linearity with the correlation of determination higher than 0.997 , which meets the criteria.

\subsubsection{Repeatability and recovery}

The repeatability and recovery of the method were assessed by analyzing the spiked samples at three different concentrations of $3.0,10,20 \mu \mathrm{g} / \mathrm{kg}$ with six replicates at each concentration. The results were shown in Table 4.

Table 4. Results of repeatability ( $R S D \%)$ and recovery ( $R \%$ )

\begin{tabular}{lcccccc}
\hline \multirow{2}{*}{ Auxin } & \multicolumn{2}{c}{ Bean sprout } & \multicolumn{2}{c}{ Potato } & \multicolumn{2}{c}{ Spinach } \\
& $\boldsymbol{R}(\%)$ & $\boldsymbol{R S D}(\%)$ & $\boldsymbol{R}(\%)$ & $\boldsymbol{R S D}(\%)$ & $\boldsymbol{R}(\%)$ & $\boldsymbol{R} S D(\%)$ \\
\hline NAA & $84.0-95.3$ & $2.9-4.6$ & $83.7-91.4$ & $5.0-8.0$ & $89.7-94.9$ & $2.9-4.5$ \\
2-NOA & $81.7-91.8$ & $1.9-7.5$ & $82.9-91.1$ & $3.6-9.9$ & $86.4-92.5$ & $2.3-4.4$ \\
4-CPA & $87.5-94.1$ & $2.0-7.3$ & $86.8-93.2$ & $2.6-6.5$ & $83.7-93.8$ & $3.8-4.1$ \\
MCPA & $89.2-96.4$ & $2.5-12.6$ & $80.1-90.5$ & $4.8-8.3$ & $90.2-95.4$ & $1.6-6.4$ \\
IPA & $91.4-95.4$ & $2.8-5.3$ & $87.4-92.8$ & $3.0-5.9$ & $89.9-95.4$ & $1.6-3.9$ \\
IBA & $89.9-94.2$ & $4.9-5.2$ & $78.9-89.2$ & $4.4-11.2$ & $80.1-89.9$ & $4.0-7.4$ \\
\hline
\end{tabular}

The recoveries of the method for analyzing vegetable, tuber, and fruit matrix were in the range of 81.7 and $96.4 \%, 78.9$ and $93.2 \%, 80.1$ and $95.4 \%$, respectively. The relative deviation of six auxin analogs in all matrices were lower than $12.6 \%$, which conformed with the AOAC International's regulation.

\subsection{Application for real sample analysis}

The method was applied for the determination of six auxins in vegetables, fruit, and tuber collected from different markets in Hanoi. The results are listed in Table 5.

Table 5. Testing of six auxins in fruit, vegetables and tuber products

\begin{tabular}{lcccccc}
\hline PGP & \multicolumn{2}{c}{ Vegetables } & \multicolumn{2}{c}{ Tubers } & \multicolumn{2}{c}{ Fruits } \\
& $\begin{array}{c}\text { Detected } \\
\text { samples }\end{array}$ & $\begin{array}{c}\text { Content } \\
(\boldsymbol{\mu g} / \mathbf{k g})\end{array}$ & $\begin{array}{c}\text { Detected } \\
\text { samples }\end{array}$ & $\begin{array}{c}\text { Content } \\
(\boldsymbol{\mu g} / \mathbf{k g})\end{array}$ & $\begin{array}{c}\text { Detected } \\
\text { samples }\end{array}$ & $\begin{array}{c}\text { Content } \\
(\boldsymbol{\mu g} / \mathbf{k g})\end{array}$ \\
\hline NAA & $0 / 30$ & $\mathrm{ND}$ & $0 / 30$ & $\mathrm{ND}$ & $0 / 30$ & $\mathrm{ND}$ \\
2-NOA & $0 / 30$ & $\mathrm{ND}$ & $0 / 30$ & ND & $0 / 30$ & ND \\
4-CPA & $5 / 30$ & $23-75$ & $0 / 30$ & ND & $0 / 30$ & ND \\
MCPA & $22 / 30$ & $3.0-7.1$ & $9 / 30$ & $3.2-3.7$ & $0 / 30$ & ND \\
IPA & $0 / 30$ & ND & $0 / 30$ & ND & $0 / 30$ & ND \\
IBA & $0 / 30$ & ND & $0 / 30$ & ND & $0 / 30$ & ND \\
\hline
\end{tabular}

ND - Not detected

The result showed that MCPA is contained with small amounts from 3.0 to $7.1 \mu \mathrm{g} / \mathrm{kg}$ in 22/30 vegetable samples such as: chayote tops, mustard greens, cucumbers, and tomato; from 
3.2 to $3.7 \mu \mathrm{g} / \mathrm{kg}$ in 9/30 tuber samples. Especially, 4-CPA was detected in 5 bean sprouts samples with content ranges from 23 to $75 \mu \mathrm{g} / \mathrm{kg}$ which is higher than the MRL regulated by EU $(10 \mu \mathrm{g} / \mathrm{kg})$. Therefore, it requires a more stringent control on this auxin analog in vegetables, particularly the bean sprout.

\section{CONCLUSION}

The method for simultaneous determination of six auxins (1-naphthalene acetic acid, 2-naphthoxyacetic acid, 4-chlorophenoxyacetic acid, 2-methyl-4-chlorophenoxyacetic acid, 3-(3-indolyl) propionic acid, indole-3-butyric acid) was developed and validated, completely satisfying the regulation of AOAC International and Europe. The method can be applied to determine six plant-growth promoters belonging to auxin group in vegetables, tubers, and fruits.

\section{ACKNOWLEDGEMENT}

We would like to thank the National Institute for Food Control for the funding of this study.

\section{REFFERENCE}

[1]. Hồng Hải, "Nhập viện vì ăn ổi vừa phun chất kích thích tăng trưởng," 14/02/2016. [Trực tuyến]. https://dantri.com.vn/suc-khoe/nhap-vien-vi-an-oi-vua-phun-chat-kich-thich-tangtruong-20160214191811562.htm [Truy cập: 20/05/2020].

[2]. Mai Loan, "Thu giữ 80.000 lọ thuốc kích thích giá đỗ từ Trung Quốc," 15/11/2016. [Trực tuyến]. https://www.doisongphapluat.com/dia-phuong/mien-bac/thu-giu-80000-1o-thuockich-thich-gia-do-tu-trung-quoc-a9091.html [Truy cập: 20/05/2020].

[3]. Y. Bai, F. Du and H. Liu, "Determination strategies of phytohormones: recent advances", Analytical Methods, vol. 2, pp. 1867-1873, 2010.

[4]. Y. Chen Z. Guo, X. Wang, C. Qiu, "Sample prepartion”, Journal of Chromatography A, vol. 1184, pp. 191-219, 2008.

[5]. European Commision, Directorate General for Health and Food Safety, "Analytical Quality Control and Method Validation Procedures for Pesticide Residues in Food and Feed", Sante/12682/2019, Implemented by 01.01.2020.

[6]. H. M.G. van der Werf, "Assessing the impact of pesticides on the enviroment", Agriculture, Ecosystems \& Enviroment, vol. 60, pp. 81-96, 1996.

[7]. M. I. A. Flores, R. Romero-González, A. G. Frenich, J. L. M. Vidal, “QuEChERS-based extraction procedure for multifamily analysis of phytohormones in vegetables by UHPLCMS/MS”, Journal of Separation Science, vol. 34, no. 13, pp. 1517-1524, 2011.

[8]. L. Ma , H. Zhang, W. Xu, X. He, L. Yang, Y. Luo and K. Huang, "Simultaneous Determination of 15 Plant Growth Regulators in Bean Sprout and Tomato with Liquid Chromatography-Triple Quadrupole Tandem Mass Spectrometry", Food Analytical Methods, vol. 6, pp. 941-951, 2013. 


\title{
Xác định đổng thời môtt số chất kích thích tăng trưởng thực vật nhóm auxin trong rau, củ và quả bẳng kỹ thuật sắc ký lỏng khối phổ hai lẩn (LC-MS/MS)
}

\author{
Vũ Ngọc Túr ${ }^{1,2}$, Đặng Thị Hiênn ${ }^{1,2}$, Nguyễn Thị Ánh Hường², Phạm Thị Ngọc Mai² \\ Hoàng Quốc Anh ${ }^{2}$, Bùi Cao Tiến ${ }^{1}$, Bùi Quang Đông1, Lê Thị Hồng Hảo ${ }^{1,2}$, Trần Cao Sơn ${ }^{1}$ \\ ${ }^{1}$ Viện Kiểm nghiệm an toàn vệ sinh thực phẩm Quốc gia \\ ${ }^{2}$ Trưòng Đại học Khoa học tụ nhiên, Đại học Quốc gia Hà Nội
}

\section{Tóm tắt}

Sắc ký lỏng khối phổ hai lần (LC-MS/MS) kết hợp với kỹ thuật chiết QuEChERS đã được ứng dụng để nghiên cứu xây dựng và thẩm định phương pháp xác định các chất kích thích tăng trưởng thực vật nhóm auxin bao gồm 4-chlorophenoxyacetic acid (4-CPA), 2-methyl-4chlorophenoxyacetic acid (MCPA), 1-naphthalene acetic acid (NAA), 2-napthoxyacetic acid (NOA), indole-3-propionic acid (IPA), indole-3-butyric acid (IBA). Phương pháp được thẩm định đạt yêu cầu về tính đặc hiệu, độ nhạy và độ chính xác trong khoảng nồng độ từ $3,0 \div 200$ $\mu \mathrm{g} / \mathrm{kg}$. Giá trị LOD và LOQ lần lượt là $1,0 \mu \mathrm{g} / \mathrm{kg}$ và $3,0 \mu \mathrm{g} / \mathrm{kg}$. Các chất phân tích có độ thu hồi trong khoảng $79,8 \div 96,4 \%$, và độ lệch chuẩn tương đối lặp lại dưới $12,6 \%$, đạt yêu cầu của AOAC. Quy trình tối ưu đã được áp dụng để xác định hàm lượng sáu chất kích thích tăng trưởng thực vật nhóm auxin trong các mẫu rau, củ và quả được thu thập từ các chợ khu vực: Mai Dịch, Đan Phượng, Giáp Bát, Bạch Mai và Ngã Tư Sở của thành phố Hà Nội. MCPA được phát hiện trong $22 / 30$ mẫu rau $(3,0 \div 7,1 \mu \mathrm{g} / \mathrm{kg})$ và $9 / 30$ mẫu trái cây $(3,1 \div 7,1 \mu \mathrm{g} / \mathrm{kg})$. Đặc biệt, 4-CPA được phát hiện với hàm lượng cao ở mức từ $23 \div 75 \mu \mathrm{g} / \mathrm{kg}$ trong mẫu giá đỗ, vượt quá dư lượng tối đa $(10 \mu \mathrm{g} / \mathrm{kg})$ theo quy định của Hội đồng Châu Âu.

Tù khóa: 4-chlorophenoxyacetic acid (4-CPA), 2-methyl-4-chlorophenoxyacetic acid (MCPA), 1-naphthalene acetic acid (NAA), 2-napthoxyacetic acid (NOA), indole-3-propionic acid (IPA), indole-3-butyric acid (IBA), LC-MS/MS, QuEChERS, rau, củ, quả. 